\author{
Н.Е. Усенов ${ }^{1}$ Б.Ш. Абдуманапов ${ }^{2}$ \\ 1,2 Абай атындагы ҚазҰПУ, \\ Алматы қ̧аласы, Қазақ̆стан
}

\begin{abstract}
ЖАНАРТЫЛҒАН БІЛІМ БЕРУ МАЗМҰНЫ АЯСЫНДА ОҚУШЫЛАРҒА ЭКОНОМИКАЛЫҚ-ГЕОГРАФИЯЛЫҚ ЗАНДЫЛЫҚТАР МЕН ҰҒЫМДАРДЫ ҚАЛЫПТАСТЫРУ
\end{abstract}

\begin{abstract}
Аң̧датпа
Бұл мақалада географиялық білімнің жаңартылған мазмұнындағы экономикалық-географиялық заңдылықтар, ұғымдар мен түсініктер жайында берілген. Сонымен қатар мемлекеттік саясатымыз және еліміздің қазіргі кездегі экономикасын жақсарту және одан әрі жетілдіру үшін білім беру саласына ерекше назар аударатындығы тілге тиек етілді. Жалпы ғылым саласында «зерттеу құзыреттілігі» ұғымы негізгі орынға ие категориялардың бірі, ол «ғылым», «зерттеу», «құзырет» ұғымдарынан құралған заманауи білім беру жүйесінің негізгі бағдары. Бүгінгі күні адамзаттың шығармашылық әрекетінің нәтижесін тиімді пайдалану арқылы ғылыми-техникалық прогресті одан әрі дамытуға болатындығы белгілі. Өйткені ол экономика, техника, ғылым, саясат және жалпы қоғам дамуының шешуші күшіне айналуда. Ғылыми-зерттеушілік құзыреттілікті қалыптастыру кез-келген ғылым аясында сәттілікке жету жолы екені сөзсіз анық. Ғылыми-зерттеушілік құзыреттілік білім алушылардың ғылыми-зерттеу дағдыларын мазмұнды орындап, дамытқан кезде ғана жүзеге асады. Оған біз жаңа ғылыми білімді жасау үрдісінде алынған білім, білік және дағдыны іс-тәжірибеде қолдану арқылы жетеміз. Сонымен қатар географиялық білімнің жаңартылған мазмұнындағы экономикалық-географиялық ұғымдары мен түсініктері туралы шетелдік ғалымдардың ғылыми көзқарастары да келтірілген.
\end{abstract}

Түйін сөздер: экономикалық-географиялық білім, жаңартылған мазмұн, қазіргі білім беру саласы, зерттеушілік құзыреттілік, шығармашыл тұлға.

\author{
${ }^{1}$ N.E.Usenov, ${ }^{2}$ Abdimanapov \\ 1,2Abai Kazakh National Pedagogical University, \\ Almaty, Kazakhstan
}

\title{
ACCEPTANCE OF ECONOMIC-GEOGRAPHICAL REGULATIONS AND CONCEPTS OF STUDENTS UNDER THE UPDATE OF THE SCHOOL EDUCATION PROGRAM
}

\section{Abstract}

This article deals with the assimilation of students studying in the updated program of geography, economic and geographical patterns, concepts and ideas. The article also writes that since at the present stage the policy of our state is aimed at the further development of the economy, the closest attention will also be paid to the development of the educational sphere.

In the field of science, the concept of "research competence" is one of the key categories, this emerging from the concepts of "science", "research", "competence" category is the main guideline of the modern education system. At present, only through the effective use of the results of a person's creative activity is it possible to advance scientific and technological progress. The formation of scientific and research competence in any field of science can lead to success. Research competence can only be realized if students acquire and further develop research skills. This can be achieved by using the knowledge gained in the new school system in practice. Also, in this study, the views of foreign researchers on economic and geographical concepts and representations in the updated program of the content of geography are presented.

Keywords: economic and geographical science, updated content, modern education system, research competence, creative personality. 


\title{
${ }_{1,2}^{2}$ Казахский национальный педагогический университет имени Абая
} 2. Алматы, Казахстан

\section{УСВОЕНИЕ ЭКОНОМИКО-ГЕОГРАФИЧЕСКИХ ЗАКОНОМЕРНОСТЕЙ И ПОНЯТИЙ УЧАЩИМИСЯ В РАМКАХ ОБНОВЛЕННОЙ ПРОГРАММЫ ШКОЛЬНОГО ОБРАЗОВАНИЯ}

\begin{abstract}
Аннотация
В этой статье речь идет об усвоении учащимися, обучающихся по обновленной программе географии, экономико-географических закономерностей, понятий и представлений. Также в статье пишется о том, что поскольку на современном этапе политика нашего государства направлена на дальнейшее развитие экономики, то и развитию сферы образования тоже будет уделяться самое пристальное внимание.

В области науки понятие «компетентность исследования» - одна из ключевых категорий, эта складывающееся из понятий «наука», «исследование», «компетентность» категория является основным ориентиром современной системы образования. В настоящее время только посредством эффективного использования результатов творческой деятельности человека возможно продвижение научно-технического прогресса.Формирование научно- исследовательской компетентности в любой сфере науки может привести к успеху. Научно- исследовательская компетентность может реализоваться только в случае усвоения и дальнейшего развития учащимися научноисследовательских навыков. Этого можно добиться путем использования полученных в новой системе школьного образования знаний, умений и навыков на практике.Также в данном исследовании приводятся взгляды зарубежных исследователей на экономико-географическиепонятия и представления в обновленной программе содержания географии.
\end{abstract}

Ключевые слова: экономико-географическауки ое образование, обновленное содержание, современная система образования, компетентность исследования, творческая личность.

Кіріспе: Қазақстан Республикасының тұңғыш Президенті Н.Ә.Назарбаевтың Қазақстан халқына «Қазақстан-2050 стратегиясы - қалыптасқан мемлекеттің жаңа саяси бағыты» 2014 ж. Жолдауында жастарға білім беруді жетілдіруге айрықша көңіл бөлінген. Елбасы: «Бәсекеге қабілетті дамыған мемлекет болу үшін біз сауаттылығы жоғары елге айналуымыз керек. Қазіргі әлемде жаппай сауаттылық жетілдірудің шыңына жеткелі -қалғалы қашан. Біздің азаматтарымыз үнемі ең озық жабдықтармен және ең заманауи өндірістерде жұмыс жасау машығын меңгеруге дайын болуға тиіс. Сондай-ақ, балаларымыздың, жалпы барлық жеткіншек ұрпақтың функционалдық сауаттылығына да зор көңіл бөлу қажет. Балаларымыз қазіргі заманға бейімделген болуы аса маңызды» - деп атап көрсеткен болатын [1,2].

Мемлекеттік саясатымыз еліміздің экономикасын жақсарту және одан әрі өсіру үшін білім беру саласына ерекше назар аударып отыр. Сондай-ақ, адам капиталын қалыптастыруды, атап айтқанда, өздігінен және шығармашылық тұрғыда кәсіби міндеттерді шеше алатын, қызметтің тұлғалық және қоғамдық мәнін саналы түрде ұғынатын, оның нәтижесіне жауап бере алатын құзыретті, бәсекеге қабілетті тұлға қалыптастыруды қамтамасыз ететін білім беру жүйесін жаңарту негізгі бағыт болып анықталған.

Сондықтан қазіргі кездегі қоғамның дамуына тән сипат білім беру жүйесін жетілдіру болып табылады, бұл өз кезегінде өзін-өзі жүзеге асыруға, басқаруға, реттеуге, қоршаған ортада әлеуметтенуге қабілетті тұлға тәрбиелеумен, заманауи өркениеттегі адам рөлінің жоғарылауымен байланысты және тұлғаның дамуына ықпал ететін өзіндік ішкі механизмдері: өзін-өзі тану, анықтау мен дамытуды белсендендіру - білім беру үдерісінің басты мақсаты болып табылады.

Жалпы орта білім беру сапасын арттыру мақсатында білім беру жүйесінің даму бағыттарын, даму траекториясын айқындау және соның негізінде күтілетін нәтижеге бағытталған құзыреттілік тұрғысынан қол жеткізуге бағытталған білім беру жүйесін жетілдірудің қажеттілігі арта түсуде.

Қазақстан Республикасының Мемлекеттік жалпыға міндетті білім беру стандартына сәйкес,«География» пәні «Жаратылыстану» білім саласына енгізілген мектептің негізгі орта және жалпы орта білім беру деңгейлерінде міндетті түрде оқытылатын пән. «География» пәнінің білім 
мазмұны оқушылардың функционалдық сауаттылықтарын қалыптастыруға бағытталған. Бұл талдамалы материалда еліміздің жалпы білім беретін мектептеріне арналған география пәні бойынша: 1) оку материалдарын талдауды; 2) оқушылардың дайындық деңгейін; 3) пән бойынша білім берудің жағдайын; 4) географияны оқытудың әдістемесі мен тәжірибесіндегі инновацияларды зерделеу және анықтау мақсаты көзделген [3,4].

Кез келген мемлекеттің шаруашылығын дамыту үшін экономикалық-географиялық жағдайдың маңызы зор болып табылады. Экономикалық-географиялық жағдай - кез-келген елдің, Дүниежүзінің экономикалық картасындағы орнын көрсетеді. Экономикалық-географиялық жағдай тиімді немесе тиімсіз болуы мүмкін.

Мектептегі география пәнінің ғылым негіздерін оқыту пәні ретінде, оқушылардың дүниетанымдық ғылыми көзқарасын қалыптастыруда үлесі зор. Окушылардың меңгерген ғылыми білімі дүниетанымның бір бөлігі болуы үшін география пәні әр тұлғаның қоршаған ортаның нақты жағдайымен қарым-қатынаста және байланыста болуында, бұл қарым-қатынастарды реттеуде және ұйымдастыруда, олардың мағынасын түсінуде бағыттаушы рөлін атқаруы тиіс.

География - Жер - адам өмір сүретін ғаламшар ретінде тұтас көзқарас қалыптастыратын оку пәні және оқушылардың бойында жалпы мәдениет пен экологиялық мәдениетті қалыптастыруда негізгі орынды иеленеді. Сонымен қатар, барлық деңгейдегі басқарушылық шешімдерді қабылдау үшін де қажет. Шаруашылықтың тиімділігін арттыру және халықтың әл-ауқатын жақсартуда да география ғылымы қажет.

Осы заманғы кезеңде әлемдік білім беру тәжірибесінде білім сапасын жетілдірудің жаңа бағытбағдарлары нәтижеге бағытталған білім беру үлгісі арқылы жүзеге асырылады. Көптеген елдердің білім берудегі ауқымды реформалары білім берудің заманауи үлгісін тарихи қалыптасқан жағымды дәстүрлерді сақтай отырып, инновациялық көзқарас-ыңғайларды пайдалануды көздейді.

Негізгі бөлім: Бүгінгі күні адамның білім алудағы сұранысы «білетін адамнан» «шығармашылық тұрғыда ойлайтын, әрекет етуге, өздігінен жетілуге қабілетті адам» үлгісіне ауысып отыр. Оқыту мен тәрбиенің өзге құрамдас бөліктерімен салыстыра келгенде, білім мазмұны түйінді және тұрақты шама болып табылады. Сондықтан оны жаңарту жұмысы жаңа білім беру парадигмасын тудырып, бірқатар қажетті педагогикалық шарттар кешенінің өзгеруіне әкеледі. Бұл білім беру қызметінің ғылыми-әдістемелік және ұйымдастырушылық-әдістемелік қолдауға да қатысты.

Географиялық білімнің жаңартылған мазмұнындағы экономикалық-географиялық ұғымдар мен түсініктер жайында айтатын болсақ, бүгінгі таңда бірінші орында тұрған ғаламдық экономикалықгеографиялық мәселелердің бірі экологиялық дағдарыстардың алдын алу адамдардың мақсатты бағытта ойластырған іс-әрекеті арқылы ғана жүзеге асады. Осыған орай экологиялық дағдарыстан шығудың жолдары іздестірілуде және оған қатысты материалдарды елімізде қабылданған «Қазақстан Республикасы Қоршаған ортаны қорғау», «Табиғи және техногенді сипаттағы төтенше жағдайлар» туралы Заңдардан, сондай-ақ «Орнықты даму үшін қоршаған ортаны қорғаудың ұлттық әрекет жоспары» сияқты экологиялық мәселелерге арналған мемлекеттік құжаттардан көруге болады [5].

Жаңартылған білім мазмұны аясында оқушылардың экономикалық-географиялық заңдылықтары мен ұғымдарын қалыптастырудың әдістемелік негіздеріне келетін болсақ, басты назар, әсіресе, топтық және жеке оқушылармен жұмыс жасауға аударылады. Бұл жерде жаңа технология жүйесінде мәнді ойындардың, семинар, пікірталастар, конференция-сабақтардың, дәріс, сынақ, топ серуендері, практикалық жұмыстардың маңызы зор. Бұл сабақтарда оқушылардың әр түрлі мәселелерді шешу жолдарын іздестіруге мүмкіншілік туғызып, олардың логикалық ойлау қабілетін дамытады, оқуға деген қызығушылықтарын арттырады.

Жаңа мазмұнға жаңа әдістер жүйесі қажет. Бүгінгі күні білім беру мекемелерінде оқыту үрдісін технологияландыру өзекті мәселелердің бірі болып табылады. Технология мен әдіс-тәсілдің арақатынасын ажырату да қарапайым мұғалім үшін кейде қиын болып жатады.

Нақтырақ айтқанда, географияны оқыту әдістемесі ғылымы дегеніміз - мектепте өтілетін пәнді оқыту және тәрбиелеу үрдісі жайлы ғылым [10].

Экономикалық география - геокеңістікте табиғат жағдайы мен ресурстары, халық және шаруашылықтың өзара байланыста орналасуы мен таралуын шаруашылықтың табиғатқа әсері және табиғаттың қоғам өміріне әсерін зерттейтін ғылым. 
Қолданбалылық тұрғыда қарағанда бұл ғылымға мынандай анықтама беруге болады: Экономикалық география нақты географиялық кеңістікте экономикалық, әлеуметтік және саяси нысаналардың орналасуы мен аумақтық ұйымдастыру ерекшіліктерін зерттейтін ғылым.

Шаруашылықтың дамуы мен орналасуы геокеңістіктің барлық көлемінде таралмаған, сондықтан экономикалық географияның зерттеу нысанасы антропосфера (экосфера), яғни, шаруашылық дамыған және орналасқан геокеңістік болып есептеледі.

Кеңестік кезеңінде Н.Н.Баранский, Н.Н.Колосовский ғалымдар мынандай анықтама берді «қоғамдық өндірістің орналасу заңдылықтары мен экономикалық аудандардың құрылуын зерттейтін ғылым». Ю.Г.Саушкин - «аумақтық әлеуметтік-экономикалық жүйелерді зерттейтін ғылым» [6,7].

Қазіргі ғалымдардың анықтамасына жүгінсек А.Ю.Скопин - «антропосфераның трансормациялануын және ақпараттық пен жүйелік бағыттары негізінде геоэкономикалық мәселелерді шешу жолдарын іздеу арқылы қоғамды аумақтық ұйымдастыруды зерттейтін ғылым. Мұнда, геоэкономикалық мәселелер деп табиғат пен қоғамның өзара байланысы әсерінен болатын жүйелі өзгерістер немесе негативтік әлеуметтік, саясаттық, экономикалық, экологиялық, технологиялық өзгерістер түсіндіріледі $[7,8]$.

Орта білім беру жүйесінің негізгі деңгейдегі 7-9 сыныптарында және жалпы деңгейдегі 10-11 сыныптарында мазмұны жаңартылған «География» пәні бойынша жасалған типтік оқу бағдарламасында қоғамның даму заңдылықтарына, «табиғат-қоғам- шаруашылық» жүйесіндегі аймақтық өзара әрекеттесулерге жасалған талдау және болжам жасауға сүйене отырып анықталған бірқатар экономикалық-географиялық заңдылықтарды зерттеу қарастырылған.

Экономикалық -географиялық заңдылықтарды зерттеу облысында оқыту жүйесінің міндеттерін жүзеге асыру, оқушылардың дағдыларын дамыту, білімдерін тереңдету мақсатында төменде аталған міндеттерді жүзеге асыру тиіс:

- табиғи және антропогендік объектілерді, құбылыстарды және процестерді қамтитын дүние жүзінің біртұтас географиялық бейнесін ашып көрсету, қоршаған ортаның аймақтық айырмашылықтарын, олардың объективтік сипатын және адамдардың өміріндегі мағыздылығын ұғындыру;

- оқушылардың санасында табиғат пен қоғамның өзара байланысына, бұл байланыстың кеңістік ерекшеліктеріне ғылыми көзқарас қалыптастыру;

- қоғамдық өнідірістің, табиғатты қорғаудың және табиғи байлықтарды тиімді пайдаланудың негіздерін ашып көрсету;

- география ғылымының негізгі ұғымдары мен терминдерін игеру;

- кеңістіктік ойлауды және картографиялық дағдыларды қалыптастыру;

- география сабақтарында алған білімдерін тәжірибе жүзінде, күнделікті өмірде пайдалана алу дағдыларын дамыту.

Қазіргі кезде Қазақстан Республикасында жалпы орта білім беру мазмұнын жаңарту аясында білім беру үдерісінің құрылымы мен мазмұнына елеулі өзгерістер енгізілуде. Білім мазмұнын жаңартудың басты мақсаты - білім сапасын көтеру.

Осыған орай, жалпы орта білім беретін мектептердегі «География» оқу пәнінің мазмұны білім алушылардың бойында ғылыми-жаратылыстану білімдерін, табиғат, қоғам және экономиканың жүйелі байланысы, Жер туралы түсініктері мен көзқарастарын, Қазақстан Республикасының әсем табиғаты және экономикасының ерекшеліктері туралы білімдерін қалыптастыруға, функционалдық сауаттылықты және жүйелі-кешенді немесе «географиялық» сананы дамытуға бағытталған.

7-9 сыныптардың бағдарламаларында экономикалық-географиялық дағдыларды дамыту екі бөлімде қарастырылған. «Әлеуметтік география» деп аталатын бірінші бөлімде «Халық географиясы» деген тарау бар. «Экономикалық география» бөліміне «Табиғи ресурстар», «Әлеуметтікэкономикалық ресурстар», «Дүниежүзі шаруашылығының салалық және аймақтық құрылымы», «Дүниежүзі шаруашылығының даму көрсеткіштері және бағыттары» тараулары енгізілген. 10-11 сыныптардың оқулықтарында жоғарыда қойылған міндеттер «Геоэкономика» бөліміндегі «Геоэкономика негіздері» тарауында жүзеге асырылады.

Жергілікті, аймақтық, ауқымды деңгейлердегі географиялық (аймақтық) еңбек бөлінісінің әсерімен қалыптасатын халықтың, табиғатты пайдаланудың және шаруашылықтың кеңістіктік құрылымы зерттеудің нақты объектілеріне жатыстырылады.

Сонымен, экономикалық және әлеуметтік географияның білім беру саласындағы басты міндеттері: 
-халық шаруашылығының салаларының мен әрекет ету облыстарының орналасу заңдылықтарын зерттеу, соның негізінде - түрлі кеңістіктік деңгейлерде материалды және материалды емес өндіріс салаларының оңтайлы орналастырылуын анықтау;

-нарықтың түрлі субъектілерінің экономикалық әрекет жасау салаларындағы шығындарын экономикалық -географиялық тұрғыдан анықтау;

-шаруашылық және әлеуметтік өнідіріс элементтерінің кешенді қызмет ету тұрғысынан оқшауланған эконокалық аудандарды экономикалық -географиялық позициядан зерттеу;

- экономикалық аудандардың және және белгілі аймақтардың жүйелеріндегі және бүкіл шаруашылық кешеніндегі жалпы халықтың, жеке мекенжайлардың, урбанизация үрдісінің орны мен рөлін, орналасу тәртібін экономикалық -географиялық зерттеу;

-аймақтың шаруашылық кешенінің жеке элементтерін: өнеркәсіптік кәсіпорындарды, ауыл шаруашылығы ұжымдарын, инфрақұрылымды және т. б. экономикалық және әлеуметтік география тұрғысынан зерттеу;

-берілген кәсіпорындардың түрлі деңгейлерді аймақтардың шаруашылық

-территориалды кешеннің салалық және аймақтық аспектілердегі тиімділігін (экономикалық негізділігін) анықтау;

-халықтың құрылымын, орналасу тәртібін, миграция үрдістерін, еңбек ресурстарын және тағы басқа даму заңдылықтарын экономикалық -географиялық зерттеу [7,9].

Қортынды: Осылайша, жоғарыда айтылғандарды ескере отырып географиялық білім заманауи әлемнің және адамзаттың тұтастығы туралы саналы түсінік екендігін байқаймыз. Қай ұстаз болмасын қазіргі күн талабына сай оқытудың ең тиімді жаңа әдіс-тәсілдерін қолдану арқылы оқушылардың білімдерін тереңдетіп, оны практикада қолдана білуге таным белсенділігін арттыруға тырысатыны анық. География пәні - өзіндік ерекшелігі бар пән екендігі белгілі. Ол жалпы құрлық, жер бетін, планетамызды, ондағы тіршілік ететін өсімдік, жануарлар дүниесін, жер бедерін, байлығын және өмір сүріп отырған бірнеше мыңдаған ұлттар мен ұлыстардың тіршілігін зерттеп үйрететін ғылым. Сондықтан, география пәнінің мұғалімі экономикалық-географиялық заңдылықтарды меңгерген, пәннің әдістемелік негіздерін терең білетін, жан-жақты білімді, есте сақтау қабілеті жоғары, жаңалыққа жылдам бейімделетін, оқушыларды тұлға ретінде қалыптастыруға ықпал ететін білікті ұстаз болуы қазіргі заман талабы болып табылады. Сондықтан, өскелең ұрпағымыз өздерін қоршаған материалдық, рухани және мәдени құндылықтарды, сондай-ақ адамның кеңістікте өмір сүруінің мәнін дұрыс түсінулері үшін, белгілі деңгейде географиялық білім мен түсінік жинақтаулары тиіс.

Пайдаланылван ддебиеттер тізімі:

1. Қазақустан Республикасының Президенті - Ұлт көшбасшысы Н.Ә. Назарбаев 2014 жылды 17 құаңтардавы Қазақсттан халқына «Қазақстан жолы - 2050: бір мақсат, бір мүдде, бір болашақ».

2. Қаратабанова Р.Ә., т.б «География» Жалпы білім беретін мектептің 8-сынып окушыларына арналzан.1-бөлім. Алматы: кітап баспасы. 2017.67-71б.

3. Окушылардың функиионалдық сауаттылывын дамытудың 2012-2016 жылдарва арналван ұлттық іс-қимыл жоспарын бекіту туралыҚазақстан Республикасы Үкіметінің қаулыссы. 25 маусым 2012 ж. № 832. Н 37 4ҚР БжҒМ Бұйрывы 3.04.2013. №115:

4. Егорина А.В., т.б. «География» Жалпы білім беретін мектептердің 7-сыныбына арналван окулық -Алматы: Атамұра.. 2017

5. Сейталиев Қ Қазақстандагы жогары педагогикалық білім берудің қъалыптасуы мен дамуы1920-1991 жж Дис...докт пед. наук.-Алматы 19972.-288б.

6. Саипов А.А. «География индустриально-инновационного развития Казахстана», Институт повышения квалификаџии педагогических работников по г.Астана 20132.

7. Каратабанов Р.А. «География» пәнінен оқу жоспарын жасау бойынша әдістемелік нұсқаулар, білім беру бавдарламалары орталыzының филиалы «Назарбаев Зияткерлік мектептері» АҚ, наурыз, 2015.131-139бб.

8. Қазақстан Республикасының білі беру жүйесінің жавдайы мен дамуы туралы Ұлттық баяндама - Астана: НЦОСО, 2014. - 292 б.

9. Усиков В., Егорина А География Казахстана (часть 2). 9 класс Автор: Год издания: 2019.-71б.

10.Усенов Н.Е., Абдуманапов Б.Ш., Мектеп географиясындагы жаңчартылган білім беру мазмұны аясында экономикалық-географиялық заңдылықтарды оқытудың аспектілері. ВЕСТНИК Серия «Педагогические науки», №4 (64), 2019 г. 339-343 бб. 